\title{
Government Expropriation and Chinese-Style Firm Diversification
}

\author{
Julan $\mathrm{Du}^{\mathrm{a}}$, Yi Lu ${ }^{\mathrm{b}}$, and Zhigang $\mathrm{Tao}^{\mathrm{c}}$ \\ a Chinese University of Hong Kong \\ b National University of Singapore \\ ${ }^{\mathrm{c}}$ University of Hong Kong
}

This Version: June 2014

\begin{abstract}
Firm diversification across unrelated businesses is prevalent in many emerging economies, in contrast to the practices in developed economies. A fundamental difference between these two types of economies concerns with the existence of sound economic institutions including in particular the institutions constraining government expropriation of private properties. In this paper, using a survey data set of private enterprises in China, we find that severer government expropriation in the form of higher informal levies, extralegal payments, and entertainment fees causes firms to diversify. We then provide two case studies to highlight the extra costs that China's private entrepreneurs need to bear for doing businesses, and how they can subsequently leverage their relations with government bureaucrats to diversify into various businesses.
\end{abstract}

Keywords: Government Expropriation; Economic Institutions; Firm Diversification; China's Private Enterprises

JEL Codes: H2; G34; L25; D23 


\section{Introduction}

Diversified firms are found to be prevalent in emerging economies such as China, India, Mexico, and Russia. And studies have shown that firm diversification leads to better performance in those emerging economies (e.g., Khanna and Palepu, 2000a; Khanna and Yafeh, 2005). ${ }^{1}$ This is in contrast to the trend in developed economies where there exist diversification discounts in corporate valuation and as a result firms adopt focused strategies for their businesses. ${ }^{2}$ What accounts for the contrasting patterns in firm diversification between emerging economies and developed economies? A fundamental difference between these two types of economies is that there exist sound economic institutions (particularly, the institutions constraining government expropriation of private properties) in developed economies but not in developing ones.

Emerging economies are characterized with pervasive and severe government expropriation of private properties. It has been suggested that private entrepreneurs in those economies may diversify their businesses in response to government expropriation (Khanna and Palepu, 1997; Ghemawat and Khanna, 1998). Albeit a reasonable conjecture, there is little rigorous empirical work on the relationship between government expropriation and firm diversification. Part of the empirical challenge lies in data limitation, particularly in cross-country studies for which comparable measures of government expropriation are difficult to come by. In addition, empirical investigation has to address various endogeneity issues. In this paper, we fill in the void by using data from the largest emerging economy, China, and carefully addressing the identification problems.

The data used in this study come from a survey of China's private enterprises conducted in 2000. Unlike their state-owned counterparts, who are the favorite kids of the socialist government of China, private enterprises are the so-called adopted kids facing systematic discriminations and substantial constraints in business entries and subsequent operations. In particular, to meet various government regulations of business entry and ongoing operations, private enterprises are subject to heavy expropriations from the government, which maintains a significant role in the economy vis-à-vis the market in regulating business entry decisions and in adjudicating commercial disputes ( $\mathrm{Du}, \mathrm{Lu}$, and Tao, 2014). Thus, the business strategy of private firms can reflect most clearly the impact of government expropriation on firm diversification. Moreover, China provides a good setting to study the effects of government quality on firm diversification strategy. Despite the fact that China is a unitary state with unified laws and political system, there exist substantial variations in the de facto protection of private property rights across its regions (e.g., Cull and Xu, 2005; Du, Lu and Tao, 2008; World Bank, 2008), which allows

\footnotetext{
${ }^{1}$ See Keister (2000), Khanna and Palepu (1996), Camp (1989), and Blasi, Kroumova, and Kruse (1997) for the case of China, India, Mexico, and Russia, respectively. For a comprehensive review, see for example Ghemawat and Khanna (1998), and Khanna and Yafeh (2007).

${ }^{2}$ For a recent survey, see Martin and Sayrak (2003).
} 
us to identify the impacts of government expropriation on firm diversification. ${ }^{3}$

To capture the extent of government expropriation, we combine three different measures used by Johnson, McMillan, and Woodruff (2002) and Cai, Fang and Xu (2011), specifically, extra-legal payments (Tan Pai in Chinese), informal levies (Za Fei in Chinese), and entertainment fees (Zhao Dai Fei in Chinese).

We find that firms reporting more severe government expropriation are more diversified. Specifically, a one-standard-deviation increase in government expropriation leads to a 0.10 -standard-deviation increase in firm diversification. These results remain robust when the regression models are modified to address typical technical concerns in empirical studies, including alternative estimation methods (Probit vs. linear probability model), instrumental variable estimation, alternative measures of firm diversification and government expropriation, controls for other types of institutions, and different sub-samples.

To shed light on how in China government expropriation leads to diversification of private enterprises, in case studies contained in Section 4, we highlight some extra costs that China's private entrepreneurs need to bear for doing businesses. First, China's private entrepreneurs generally need to go through complicated and characteristically opaque business entry regulations to get their businesses started. Second, even after setting up their businesses, those entrepreneurs would still be constantly disturbed with ongoing levies on business operations imposed by governments, often in the name of fulfilling corporate social responsibility.

Those two types of costs point to interesting interactions between China's private entrepreneurs and its government bureaucrats, who are in charge of both entry approvals and ongoing business regulations. Private entrepreneurs have to spend much time to first get acquainted with those bureaucrats, and then build up personal trust with them. Private entrepreneurs need to make financial contributions to relieve the regional fiscal burden and help build up bureaucrats' signature projects. Furthermore, private entrepreneurs may need to nurture close relationships with those bureaucrats and/or their family members through gifts and favors.

Only after private entrepreneurs establish relations and build trust with relevant bureaucrats can they obtain licenses to do business in the regions and industries administered by those bureaucrats. However, those private entrepreneurs can then leverage the relationship-specific capital that they build up with relevant bureaucrats in entering new profitable industries upon their emergence and bidding for government procurement contracts often in new business lines, both of which result in diversification into often

\footnotetext{
${ }^{3}$ Compared with cross-country studies, our cross-region study has two advantages: first, comparable data (say, for government expropriation) are more readily available for sub-national units; and second, it avoids the difficulty of controlling for differences in culture, political system, legal system, and religion across countries in international studies so that we could minimize the impact of various confounding factors.
} 
unrelated businesses. ${ }^{4}$ In Section 4, we argue that diversification across unrelated businesses within a region (industrial diversification) is often a more viable strategy for private firms than expanding their existing business lines across regions (geographical diversification). This Chinese-style corporate diversification is obviously due to the power of the state vis-à-vis the market in the economy on one hand and the systematic discriminations against private enterprises on the other hand. In regions with severer government discriminations against private enterprises and hence higher government expropriations, government bureaucrats typically have more discretion over business regulations. Consequently, the relationship-specific capital that private entrepreneurs build up with relevant bureaucrats will be more valuable in winning for them favorable treatments from bureaucrats, i.e., private entrepreneurs will obtain a higher degree of de facto protection of their private property rights and will be more able to ride on the capital to conduct business in multiple lines of business. Hence, we expect to observe a positive relationship between government expropriation and firm diversification.

Our study is related to the long-standing resource-based view of corporate diversification, namely, corporations might have advantageous physical resources (such as patents and unique equipment) and intangible resources (such as brand), which allow corporations to diversify into new industries where the portfolio of these resources will be applicable and confer competitive advantage. ${ }^{5}$ Clearly, the Chinese-style diversification is built upon a special type of corporate resource, i.e., the relations and trust that private entrepreneurs build up with relevant bureaucrats, which are obviously transferable across industries leading to corporate diversification.

Nonetheless, while the Chinese-style diversification is an organizational response to imperfect institutional environment, it most likely involves excessive diversification compared with the benchmark scenario with good institutional environment for private businesses such as that in developed economies. Consequently, it does incur efficiency losses with some social welfare implications. Firstly, the flip side of the excessive firm diversification is a scaled-down operation size for each business line, which implies some efficiency losses. Secondly, private entrepreneurs who enter into new lines of business due to their relationship-specific capital with relevant bureaucrats may not be the most efficient and most qualified producers. In this sense, the Chinese-style diversification is expected to have much worse efficiency consequences than does the resource-based diversification in developed economies.

This paper is part of a growing literature focusing on how firms change their business

\footnotetext{
${ }^{4}$ Consistent with the findings in the literature on economic institutions, government expropriation clearly dampens firm investment incentive. For example, high one-time setup costs deter firm entry, while high levies reduce profit-maximizing scale and hence the equilibrium investment. However, what we are concerned in this paper is the impact of government expropriation on firm diversification given the size of investment.

${ }^{5}$ See, for example, Silverman (1999).
} 
strategies and practices in response to poor economic institutions. Examples include the use of relational contracting instead of formal one in Vietnam where the courts are incompetent (McMillan and Woodruff, 1999), the use of informal trade credit in China where private enterprises face discrimination in accessing formal financing (Brandt and Li, 2003), and the shift toward underground business in face of over-regulation and high taxes in Eastern Europe and Russia (Johnson, Kaufmann, and Zoido-Lobaton, 1998). Most related to this paper is the literature on the innovations in organizational strategies in China in response to its imperfect and evolving institutional environment, such as township-village enterprises or TVEs (Che and Qian, 1998; Jin and Qian, 1998; Li, 2003; $\mathrm{Li}$ and Rozelle, 2003), and political participation of China's private enterprises (Bai, Lu and Tao, 2006; Li, Meng and Zhang, 2006).

The rest of the paper proceeds as follows. Data and variables are introduced in Section 2, and the main empirical findings are presented in Section 3. In Section 4, we provide two case studies illustrating the Chinese-style diversification under state capitalism. The paper concludes with Section 5 .

\section{Data and Variables}

The dataset used in this paper is from the Survey of China's Private Enterprises conducted in 2000. ${ }^{6}$ To achieve a balanced representation across all regions and industries in China, the Survey used multi-stage stratified random sampling method. The total number of private enterprises to be surveyed was first determined. After that, six cities/counties were selected from each of the 31 regions (which refer to province-level administrative units in China, and include 22 provinces, 4 municipalities directly under the supervision of the central government, and 5 minority autonomous regions), which included the capital city of the region, one prefecture-level city, one county-level city, and three counties. Next, the number of private enterprises to be surveyed in each region was determined by the product of the percentage of the region's share of private enterprises in the national total and the total number of private enterprises in the survey. The same method was used to determine the number of sample firms in every city/county and industry. Finally, private enterprises were randomly chosen for each sub-sample. The dataset contains 3,073 initial observations. After deleting those observations with no industry code, we obtain the final sample of 2,798 observations.

The use of data from private enterprises, instead of state-owned enterprises or publiclylisted firms, offers two additional advantages. First, unlike private firms that rely on themselves to achieve firm survival and growth, China's state-owned enterprises conduct

\footnotetext{
${ }^{6}$ The Survey was conducted jointly by the United Front Work Department of the Central Committee of the Communist Party of China, the All China Industry and Commerce Federation, and the China Society of Private Economy at the Chinese Academy of Social Sciences.
} 
business under the auspices of national and regional governments. Property rights protection is a much less concern to state-owned enterprises, and the de facto property rights protection they enjoy exhibits much less variation across regions than that private firms face. Second, the overwhelming majority of private firms in China are individually-owned ventures, or partnerships, or individual- or family-controlled limited liability companies (Asian Development Bank, 2003), where agency problem of corporate management is not a prominent issue. Hence, compared with the studies using data of publicly-listed firms, our focus on private enterprises allows us to isolate the impacts of property rights protection on firm diversification from those of agency costs between management and owners.

\subsection{Measurement of Firm Diversification}

The dependent variable in this study is about the extent of firm diversification. One question in the Survey asks the entrepreneurs what are the primary industry and secondary industries they are engaged in. The classification of industries in the Survey is as follows: (1) agriculture, forestry, animal husbandry, and fishing; (2) mining; (3) manufacturing; (4) electricity and gas; (5) construction; (6) geology and irrigation works; (7) transportation; (8) commerce and restaurant services; (9) finance and insurance; (10) real estate; (11) social services; (12) public health and sports; (13) education and culture; (14) science and technology; (15) others. ${ }^{7}$ Of all 2,798 observations, 1,864 firms have investment in only one industry, 703 firms in two industries, 144 firms in three industries, and the remaining 87 are engaged in four industries. A dummy variable Diversification is constructed, which takes value one if the firm has investment in more than one industries and value zero otherwise. For robustness check, a categorical variable Number of Industries is constructed, which takes value zero, one, two and three if a firm has investment in one, two, three and four industries, respectively. Table 1 reports summary statistics of the data. Referring to Table 1, we find that the mean values of Diversification and Number of Industries are $0.334( \pm 0.472)$ and $0.447( \pm 0.733)$, respectively. ${ }^{8}$

Compared with some of the existing studies on vertical integration (e.g., Fan, Huang, Morck, and Yeung, 2008; Acemoglu, Johnson, and Mitton, 2009; Du, Lu, and Tao, 2012), our measure incorporates both vertical and horizontal diversifications, and is likely to capture the allocation of investment into unrelated industries given the broad classification of industries adopted in the Survey. This allows us to examine more clearly whether government expropriation affects firm diversification that is not primarily driven by the

\footnotetext{
${ }^{7}$ There are 268 firms choosing "others" as their primary line of business. Our main results remain robust when these observations are excluded from the sample.

${ }^{8}$ A commonly-used measure of diversification is the Herfindahl Index, which is the sum of square of sales share from each industry. Due to data limitation, however, we do not have the sales figures for each industry, and have to resort to the use of number of industries as our measure of firm diversification.
} 
scope economy in production processes.

However, our measure may underestimate the extent of firm diversification and, consequently, the impacts of government expropriation on firm diversification for two possible reasons. First, the industry categories classified in the Survey are very broad (even broader than the two-digit SIC codes in China). For example, a firm making both toys and airplanes, two very different products, is viewed as focusing on one industry - manufacturing. To the extent that expropriation may lead to diversification within our broadly-defined industries (e.g., making toys and airplanes within the general category of manufacturing), our measurement of firm diversification would lead to an underestimation of the expropriation effect. Second, some private firms in China are organized as group firms, with many independent units doing different businesses. If the Survey is done at the unit level, we would not observe the true extent of diversification of the relevant group firm, which would again lead to an underestimation of the expropriation effect.

\subsection{Measurement of Government Expropriation}

According to North (1991), property rights protection concerns with the economic institutions constraining government expropriation. Specifically, in emerging economies, government expropriation is usually consisted of one-time setup costs of doing business and ongoing levies on business operations. ${ }^{9}$

China has had weak legal protection of private property rights. Private enterprises were not even formally permitted to exist until 1988 with the enactment of the Private Enterprise Administration Act, which was ten years after the initiation of China's economic reform. Only in 2004 did China make landmark amendments to its constitution to protect private property rights. After 14 years of heated debate, preparation and drafting, China passed in 2007 the Property Rights Law to make a further step forward to the protection of private property rights. But at the same time law enforcement is rather weak as judges are not well trained and their independence is dubious at best (Clarke, 1996).

In the meanwhile, local governments at different levels have provided a minimum level of property rights protection. Under fiscal decentralization, regional governments were encouraged to promote the private enterprises under their jurisdiction that contribute

\footnotetext{
${ }^{9}$ While the expropriation of private properties in the form of extralegal payments, informal levies and entertainment fees are often imposed by government officials in the name of undertaking some public projects or financing some local events, they might well be disguises for bureaucrats to enhance their private benefits (i.e., a form of corruption). For the survey data used in this study, the correlation between extralegal payments/informal levies/entertainment fees and corruption (an index constructed based on the reply to the survey question regarding the need for the government policies against corruption) is indeed positive, albeit small in magnitude, implying that property rights protection and corruption are not identical. Moreover, our regression results are robust to the inclusion of this index of corruption.
} 
to the local tax revenues and create employment opportunity. They made changes to their policies to accommodate the rise of private business interests by providing de facto property rights protection (Wu, 2003; Zhang, 2006). Furthermore, because of the lack of formal and unified legal institutions for the protection of private properties, the de facto property rights protection provided by regional bureaucrats varies substantially across regions (Cull and Xu, 2005; Lu, Png, and Tao, 2013; World Bank, 2008). According to the World Bank report on "Doing Business in China", the number of days needed for registering private properties ranges from 28 in Chongqing to 78 in Lanzhou, and the percentage of registration costs in the value of the private properties varies from $3.1 \%$ in Beijing to $12.6 \%$ in Guiyang (World Bank, 2008).

Nonetheless, the de facto property rights protection provided by the regional bureaucrats comes at a great cost to the private enterprises. Regional bureaucrats often enlist those private enterprises to undertake some public projects including bureaucrats' signature projects, which help fill in the gap in fiscal balances and enhance bureaucrats' private benefits. They also impose capricious and discretionary taxes and levies on those private enterprises to directly contribute to the budgetary revenues and off-budgetary accounts (Asian Development Bank, 2003).

In practice, there is an amazingly wide variety of extra-legal payments and informal levies imposed on private enterprises. According to a news report from Hong Kong Economic Journal on June 10, 2011, in Dongguan City, Guangdong Province, a manufacturing hub in South China, an export-oriented small or mid-sized private enterprise is subject to numerous taxes, fees and charges, ranging from property tax, customs space charges, and embankment protection costs to additional education tax and factory structure area management fee. ${ }^{10}$ Some of them may be standard taxes such as land and property taxes, while the majority of them are obviously fees and charges imposed by provincial and local governments in a discretionary manner. A striking characteristic of these levies is that they are often imposed on private firms in the name of supporting local public infrastructure projects and other public goods provision. Examples include the embankment protection costs, the security costs, and the additional education tax. These are window dressing tactics to link these surcharges with corporate social responsibility to enhance the legitimacy of these levies. Many of these charges exist in the form

\footnotetext{
${ }^{10}$ The news report in the Hong Kong Economic Journal lists the following items of taxes and fees. (1) Labor reallocation fees paid to the local Labor Bureau, which is 9 Yuan per worker; (2) Land tax, which is rated at least 3.5 Yuan per square meter; (3) Property tax, approximately $5-10 \%$ of property value; (4) Fees charged by the customs, which are five ten thousandths of export value; (5) Customs space charges imposed by the provincial Commission of Foreign Economy and Trade, which is levied at a rate of five ten thousandths of export value; (6) Embankment protection costs at a rate of five thousandths of export value payable to provincial and local governments; (7) Additional education tax imposed by provincial and local governments, which is $8 \%$ out of the value-added tax; (8) Security costs charged by the local police bureau, which are 50 yuan per employee; (9) Land use overhead expenses at a rate of 0.5 yuan per square meter per month; and (10) factory structure area management fee, levied at 5 yuan per square meter per month.
} 
of paying a certain proportion of firms' business proceeds to local governments. Meanwhile, in maintaining their relations with government officials, private entrepreneurs need to entertain them through eating, drinking and karaoke, and lavish them with gifts and sports club membership. These expenses comprise a significant portion of a firm's total value added. For example, Cai, Fang, and Xu (2011) find that the entertainment costs can be as high as 3 percent of a firm's total value added.

To capture the severity of government expropriation, we follow Johnson, McMillan, and Woodruff (2002) and Cai, Fang and Xu (2011) in constructing three different measures, specifically, extra-legal payments (Tan Pai in Chinese), informal levies (Za Fei in Chinese), and entertainment fees (Zhao Dai Fei in Chinese).

In the Survey, there are questions asking private entrepreneurs to assess the severity of extra-legal payments and informal levies in the region they are operating. The replies (ranging from 1 to 3 ) are used to construct two variables, Extra-legal Payment and Informal Levy, with a higher value indicating a less severe problem. ${ }^{11}$ Meanwhile, there are questions about entertainment fees and total net profits, and the replies to these questions are used to construct the ratio of entertainment fees to the profits, Entertainment Fee. We then use the principal component method to combine them and re-scale the generated, single index (denoted as Government Expropriation) so that a higher value indicates severer government expropriation. However, as there is quite substantial missing information on entertainment fees (i.e., an attrition of more than $50 \%$ of the whole sample), we use the first two variables (i.e., Extra-legal Payment and Informal Levy) for the construction of Government Expropriation in the benchmark analyses, and include the third variable (i.e., Entertainment Fee) as well in a robustness check.

Referring to Table 1, we observe that Government Expropriation (the principal component of Extra-legal Payment and Informal Levy) has a mean value of 0.000 and a standard deviation of 1.296. Clearly, there are significant variations across firms in the severity of government expropriation. Many of the variations come from the cross-region variations in the protection of private properties. Meanwhile, there are still some variations across firms within the same region, which could be due to the underlying firm characteristics and entrepreneurial characteristics such as political connections (Li, Meng, Wang, and Zhou, 2008).

\subsection{Other Institutions}

To isolate the effect of government expropriation on firm diversification, we control for other aspects of institutions, such as contracting institution, financial institution, taxation

\footnotetext{
${ }^{11}$ According to the "Report on China's Private Enterprises Development" by China's State Bureau for Industry and Commerce in 2005, the extralegal payments to and informal levies by the government were about $27.4 \%$ of the firms' total legitimate tax payment, $75.8 \%$ of their after-tax net profits, and $145.9 \%$ of their dividend income to shareholders.
} 
policy, and discrimination against private ownership.

Indeed, the prevailing studies of corporate diversification in emerging markets typically emphasize the importance of business groups in generating internal capital markets to overcome the lack of access to external finance in a weak financial system, and in internalizing transactions within the boundary of a firm to overcome inadequate external contracting institutions, etc. ${ }^{12}$ No doubt the Chinese economy, like most emerging market economies, also suffers from the deficiencies in these dimensions of institutional development. Thus, by controlling for these various aspects of institutions, we can differentiate the impacts of government expropriation from those of other institutions in promoting corporate diversification. Specifically, in the Survey, there are questions asking private entrepreneurs to assess the need in the region they are operating for improving contracting institutions, for improving bank loan policy, for improving taxation policy, and for ensuring equal treatment for enterprises of different ownership structures. The replies to these questions (either one if the answer is affirmative or zero otherwise) are used for constructing, respectively, Contracting Institutions, Financial Institution, Taxation Policy, and Equal Treatment.

\subsection{Other Control Variables}

To deal with the omitted variables bias, we control for entrepreneurial characteristics, firm characteristics, region characteristics, and industry dummies. Variables related to entrepreneurial characteristics include: his/her human capital, i.e., Age (the age of an entrepreneur), Education (the number of years of schooling), Managerial Experience (the number of years of having a managerial position before the entrepreneur started his/her own business), and SOE Cadre (a dummy variable indicating whether an entrepreneur used to be a manager in a state-owned enterprise); his/her political capital, i.e., Government Cadre (a dummy variable indicating whether an entrepreneur used to be a government official), $C P C$ Membership (a dummy variable indicating whether an entrepreneur is a member of the Chinese People's Congress (CPC)), and CPPCC Membership (a dummy variable indicating whether an entrepreneur is a member of the Chinese People's Political Consultative Conference (CPPCC) $) ;{ }^{13}$ and his/her social capital, i.e., Donation (a dummy variable indicating whether an entrepreneur has made any donation) and Social Status (perceived by the entrepreneur). ${ }^{14}$ If a firm makes donations, the firm may have better social image and the entrepreneur is regarded as fulfilling her/his social respon-

\footnotetext{
${ }^{12}$ See, for example, Khanna and Palepu (2000b).

${ }^{13} \mathrm{CPC}$ is the legislature and is regarded as the highest organ of state power in China while CPPCC is the political advisory organ to the Chinese People's Congress (legislature) and the government (administration).

${ }^{14}$ Here Social Status is a categorical variable ranging from 1 to 10 based on the entrepreneur's reply to the survey question regarding his/her social status, with a higher value representing a lower social status.
} 
sibility. The self-perception of social status may reflect the social capital resources the entrepreneur has access to.

Firm characteristics include Firm Age (logarithm of years since establishment) ${ }^{15}$ and Firm Size (logarithm of employment). To capture the general region characteristics, we use the Logarithm of GDP per capita as it is a comprehensive indicator of the level of economic development in different regions.

Human capital endowment may affect the ability of entrepreneurs to enter new industries in response to new developments of different industries. Political capital may facilitate entrepreneurs' entry into new industries by going through entry regulations smoothly. Social capital may help entrepreneurs to acquire information about new business lines and smoothly conduct business operations after diversification into new businesses. We include Firm Age and Firm Size to incorporate the consideration that a firm would naturally diversify its investment across industries when it grows over time.

Descriptive statistics of all key variables are given in Table 1.

\section{Impacts of Government Expropriation on Firm Di- versification}

\subsection{Comparison of Diversified Firms and Focused Firms}

We first examine the differences in government expropriation, entrepreneur and firm characteristics between the group of diversified firms (Diversification=1) and the group of focused firms (Diversification $=0$ ). Table 2 presents the sample mean and median values of some key variables for the two groups and the t-statistics of sample mean comparison tests and the z-statistics of the Wilcoxon tests assessing whether the two samples of firm observations come from the same distribution.

The mean and median values of government expropriation for the focused firm group are -0.090 and -0.457 respectively, which are statistically significantly much lower than those for the diversified firm group (0.173 and 0.550 respectively). This suggests a strong positive association between government expropriation and firm diversification.

Next, we turn to entrepreneur characteristics. Looking at entrepreneurs' human capital, we find that entrepreneurs of the diversified firm group have higher education qualifications, are younger in age, have more managerial experience, and were more frequently SOE cadres than the entrepreneurs of the focused firm group. In terms of political capital, entrepreneurs of the diversified firm group had been more frequently government cadres before they became business people and are more likely to be CPC and CPPCC members,

\footnotetext{
${ }^{15} \mathrm{~A}$ firm could be first established as a private enterprise. It could also be established as other types of enterprises, but subsequently transformed into a private enterprise. In one of the robustness checks, we focus on the subsample of firms first established as private enterprises.
} 
which point to a higher level of political endowment for entrepreneurs of diversified firms. Similarly, entrepreneurs of the diversified firm group typically have more social capital; they are more likely to make donations and perceive themselves as enjoying higher social status when compared with the entrepreneurs of focused firms. All the differences between the two groups in entrepreneurial characteristics are statistically significant.

Then we look at the key firm characteristics variables. Diversified firms are typically larger in size and longer in history than do focused firms, which are consistent with our prediction that larger and older firms have a stronger tendency to diversify their businesses.

Finally, it is interesting to note that, compared with the entrepreneurs of the focused firms group, entrepreneurs of the diversified firms group perceive a higher level of needs to improve contracting institutions, loan policy, and taxation policy, and provide equal treatment for firms with different ownership structures. Hence, it is important to control for these institutions to isolate the effect of government expropriation on firm diversification.

\subsection{Benchmark Regression Results}

To systematically investigate the impacts of government expropriation on firm diversification, we estimate the following equation:

$$
\text { Diversification }_{\text {fir }}=\mu+\alpha \cdot R_{f i r}+\mathbf{X}_{f i r}^{\prime} \gamma+\varepsilon_{f i r}
$$

where $f, i, r$ represent firm, industry, and region, respectively; Diversification fir $_{\text {mea- }}$ sures the extent of diversification; $R_{\text {fir }}$ is the measure of the severity of government expropriation; $\mathbf{X}_{\text {fir }}$ is a vector of entrepreneur and firm characteristics, and industry and region dummies; and $\varepsilon_{f i r}$ is a random error term.

In general the standard errors for micro-level data need to be adjusted for possible clustering to deal with the heteroskedasticity problem. However, in practice, when the number of clusters is small (i.e., less than 42), the clustered standard errors could be misleading (e.g., Wooldridge, 2003, 2006; Angrist and Pischke, 2009). As the number of clusters in our study is 31 , we use instead the White-robust standard errors.

To estimate specification (1), we use the ordinary-least-squares (OLS) method, instead of the nonlinear estimation methods such as Probit. This is because though nonlinear estimation is more efficient, it requires assumptions on functional forms and error distributions. Moreover, nonlinear estimation becomes considerably more complicated with instrumental variable estimation. ${ }^{16}$ Nonetheless, for ease of comparison, we also report the Probit regression results.

\footnotetext{
${ }^{16}$ For more discussion on the differences between OLS and nonlinear estimation, please see Angrist and Pischke (2009).
} 
The OLS estimation result of specification (1) is presented in Column 1 of Panel A, Table 3. It is found that government expropriation has a positive and statistically significant impact on firm diversification. Specifically, a one-standard-deviation increase in government expropriation leads to a 0.10-standard-deviation increase in firm diversification. Panel B of Table 3 reports the corresponding result of Probit regression, which is very similar to that of OLS estimation.

In Columns 2-7, we stepwisely include control variables related to entrepreneurial characteristics (i.e., human capital, political capital, and social capital), firm characteristics (i.e., firm age, and firm size), other institutions (i.e., contracting institutions, financial institutions, taxation policy, and equal treatment), regional dummies, and industry dummies. Clearly, compared with Column 1 of Table 3, the results regarding the impacts of government expropriation on firm diversification remain robust to these controls.

Note that our results are robust to the control of firm size, indicating that for a given size of investment there are still significant impacts of government expropriation on firm diversification. ${ }^{17}$ In other words, our study shows that government expropriation induces firm diversification even though government expropriation may adversely affect investment incentive. Meanwhile, our results are robust to the inclusion of various other institutions, which allows us to isolate the impacts of government expropriation and differentiate our study from those focusing on the impacts of contracting institutions on vertical integration (Fan, Huang, Morck, and Yeung, 20087; Acemoglu, Johnson, and Mitton, 2009; Du, Lu, and Tao, 2012).

\subsection{Instrumental Variable Estimation}

Despite a long list of control variables $\left(X_{f i r}^{\prime}\right)$ included, the residual may still be correlated with our regressor of interest, which could then cause our above estimated results to be biased.

To further deal with this endogeneity concern, we adopt the instrumental variable estimation approach. The rationale of our proposed instruments (all of which are proxies for the level of government expropriation in region $r$, denoted by $R_{r}$ ) is that $R_{r}$ is orthogonal to the unobserved firm characteristics (denoted by $\omega_{\text {fir }}$ ). There are several reasons why this assumption may be satisfied in our analysis. First, as the protection of private properties was not written into the Constitution until March 2004, there was no formal channel during our sample year (i.e., 1999) for private entrepreneurs to constrain regional government expropriation. Second, as very few private entrepreneurs were members of the Chinese People's Congress (i.e., 34 out of 2,798 in our sample), it was difficult for individual entrepreneurs to use this highest organ of legislative power in China to

\footnotetext{
${ }^{17}$ Note that here firm size is measured by the logarithm of employment. But our results are qualitatively equivalent when firm size is measured by the logarithm of total assets.
} 
constrain regional government expropriation. Third, as the unobserved firm characteristics $\omega_{\text {fir }}$ is the residue after controlling for a long list of variables, including particularly entrepreneurial human capital, political capital and social capital, it is hardly possible for this unobserved firm characteristics to constrain regional government expropriation. One may still argue that entrepreneurs have some unobserved characteristics that could be used to constrain regional government expropriation. However, for such individual characteristics to have any influence, it requires the collective action by all those entrepreneurs with similar unobserved characteristics, which is unlikely given that our sample firms are randomly chosen and that private enterprises only constitute a small share of the enterprises in each region.

Specifically, we use three alternative proxies of $R_{r}$ as the instrumental variables, that is, the average assessment of the severity of government expropriation by other surveyed firms in the same region, an index of property rights protection compiled by Fan, Wang, and Zhu (2003), and a historical proxy of the level of regional government expropriation - the distribution of domestic banks across China's regions in 1937. For more detailed discussion on the relevance of these instruments, see Lu, Png, and Tao (2013), and Acemoglu, Johnson, and Robinson (2001, 2002).

The regression results using these instrumental variables are reported in Table 4 . The relevance condition of the instrumental variables is confirmed by the highly significant correlation between the instrumental variable and the endogenous variable (Government Expropriation), and the result of the Anderson canonical correlation LR statistic (Panel B of Table 4). Meanwhile, the concern for weak instrument is ruled out by the result of the Cragg-Donald F-statistic (Panel B of Table 4). ${ }^{18}$ Panel A of Table 4 shows that Government Expropriation, being instrumented, still has a positive and statistically significant impact on firm diversification. ${ }^{19}$

Admittedly, all of these three instruments have their strengths and weaknesses. However, the consistent and robust findings obtained using these instrumental variables lend strong support to the effect of government expropriation on firm diversification.

\subsection{Robustness Checks}

We first investigate whether our main results are robust to an alternative measure of firm diversification, Number of Industries, which takes value zero, one, two and three if the firm has investment in one, two, three and four industries, respectively. The

\footnotetext{
${ }^{18}$ The Cragg-Donald F-statistic values for our regressions are significantly above the value of 10 , which is considered as the critical value by Staiger and Stock (1997).

${ }^{19}$ Note that the instrumental variable estimates are much larger than the corresponding OLS estimates. The increase in the magnitude suggests the existence of unobservables $\omega_{\text {fir }}$ that is correlated with government expropriation and firm diversification in different directions. Another possibility is the noisy measurement of a firm's perception of government expropriation, which could then bias the OLS estimates downward to zero.
} 
instrumental variable estimation results are reported in Column 1 (including Panels A and B) of Table 5, where Number of Industries is instrumented by the Fan-Wang-Zhu index. It is found that government expropriation still has a positive and statistically significant causal impact on firm diversification. The OLS results shown in Panel $\mathrm{C}$ of Table 5 are similar.

In Column 2, we include Entertainment Fee in the construction of our measure of government expropriation. Despite a significant drop in sample size, we still find a significant effect of government expropriation on firm diversification, with its magnitude becoming even larger.

Some of China's private enterprises were transformed from state-owned enterprises as a result of privatization. State-owned enterprises are known for pursuing diversification because of agency costs consideration. Furthermore, state-owned enterprises might also have been encouraged by the governments to merge to form conglomerates or enterprise groups. Thus a potential concern is that the degree of firm diversification could be due to the legacies of pre-privatization practices. To alleviate this concern, we restrict our sample to those firms that started from scratch as private enterprises, and repeat the analysis. As summarized in Column 3 of Table 5, our main results are robust to this subsample.

As some firms may have businesses across various regions, their decisions on diversification should be affected by the severity of government expropriation in those various regions. However, our measure of government expropriation is based on entrepreneurial perception of the regions where their headquarters are located. Consequently, our results regarding the impacts of government expropriation on firm diversification could be biased if firms have substantial businesses outside of their headquarters' regions. To address this concern, we restrict our sample to those firms with the majority of businesses conducted in the same regions where their headquarters are located. ${ }^{20}$ As reported in Column 4 of Table 5, our main results remain robust within this subsample.

\section{Discussion: Chinese-Style Diversification under State Capitalism}

The Chinese economy is widely regarded as following a model of state capitalism where the state controls the economy through widespread state ownership and adopts discriminatory policies against private ownership in the form of extensive and opaque government regulations. Compared with their counterparts in developed economies with good transparency, level-playing fields and appropriate levels of regulations, private entrepreneurs

\footnotetext{
${ }^{20}$ In the Survey, there is a question asking the firm the percentage of sales within the region where its headquarters is located. If the percentage exceeds $50 \%$, the firm is classified as one with the majority of its businesses conducted in the same region where its headquarters is located.
} 
under China's state capitalism typically bear extra costs of doing business in order to go through administrative procedures.

Firstly, private entrepreneurs in China have to incur a substantial amount of one-time overhead, setup costs, which are on top of the fixed costs associated with starting any specific line of business. These setup costs mainly consist of two parts. The first one is the excessive time and monetary costs entrepreneurs have to bear in going through government red tape, i.e., complicated and characteristically opaque business entry regulations. The second part is the costs to seek and establish connections with bureaucrats who have sweeping powers of approving business entry applications and issuing business licenses. Since the administration of entry regulations depends on the subjective and often arbitrary interpretation by relevant government officials, private entrepreneurs have to spend much time to first get acquainted with those government officials, and then please them. To this end, private entrepreneurs may need to support some "image projects" or signature projects that are launched not so much for the interests of people but mainly to show off the "correct leadership" or administrative performance of officials in charge. Furthermore, private entrepreneurs may need to nurture close relationships with bureaucrats and/or their family members through gifts and favors, who have powers to allocate government contracts, distribute loans from state banks, etc. Only after paying for these explicit and implicit costs are private entrepreneurs able to obtain approval or licenses for establishing business. In other words, private entrepreneurs have to bear large setup costs to satisfy numerous regulatory requirements and curry favor with officials to acquire the rights to do business.

Because government expropriation of private properties (including outright corruption of government officials) is illegal on paper (or by the disciplines of China's Communist Party), although much of the expropriation could be disguised under different names and causes, each bureaucrat is typically cautious and establishes close relationships with only a small number of selected business people whom she/he trusts. The small set of trusted business people, in turn, develop relationships specific to the relevant bureaucrat, and are able to go through regulations to get their businesses started and operated in an environment that is discriminatory against private enterprises. The specificity of the relationship as well as the ease or privileges of doing business implies that at a given point of time, the rights to do business are specific to the region or industry that the bureaucrat is in charge of and thus are not transferable to other regions or industries. Over time when the bureaucrat moves across regions and/or industries, the rights to do business might extend or shift to other regions and/or industries where the bureaucrat administers.

Secondly, after setting up their businesses, private entrepreneurs need to continue to please bureaucrats to maintain their rights to do business. They need to continue to provide financial assistance to bureaucrats to help relieve regional fiscal burden and 
support signature projects launched by the bureaucrats. Typically, private enterprises are imposed with informal levies and extralegal payments, often handed down to firms in the name of fulfilling corporate social responsibility such as upholding labor rights, maintaining environmental quality, contributing to local public projects or public goods provisions, etc. Moreover, private entrepreneurs need to keep giving gifts and favors to bureaucrats and/or their family members to maintain close connections and keep their business operation smooth. All these ongoing levies and the time and monetary costs needed for keeping the relations with bureaucrats are the extra variable costs, again on top of the usual variable costs associated with any specific line of business.

This kind of interaction between bureaucrats and entrepreneurs points to the intersection of money and power under China's state capitalism, which is expected to shape the Chinese-style firm diversification across industries. Firstly, the identity of profitable industries changes with the new developments in the economy over time. By maintaining the relationship-specific rights to do business, private entrepreneurs can have privileges in obtaining business licenses and entering new profitable industries upon their emergence. Secondly, with massive state control of the economy, the Chinese governments at various levels often launch large-scale government-sponsored projects backed by fiscal revenues, which would involve numerous government procurement plans. The relationship-specific rights to do business would enable private entrepreneurs to be treated favorably in bidding for government procurement contracts. As these government projects typically cover various socioeconomic aspects and the industry identity of the projects changes from time to time, the winning private entrepreneurs might need to expand into new industries from time to time after obtaining government contracts.

The Chinese economy is characterized with substantial disparity in the quality of economic institutions across regions. In regions with slower progress in market economy development and weaker legal institutions, the bureaucrats face fewer constraints in expropriating private properties. In other words, in those regions, entrepreneurs have to incur a larger amount of irregular levies, extralegal payment and bribes to build trust and maintain their relations with the bureaucrats. The flip side is that in those regions with such high extra costs of doing business (i.e., both the setup costs and the ongoing costs for building and maintaining relations with the bureaucrats, on top of the usual fixed costs and variable costs for doing business) the bureaucrats typically have more discretionary power to grant favorable treatments (e.g., government procurement contracts) to these entrepreneurs, which allows entrepreneurs to enter new business lines. Thus, it is not surprising that firms often display a higher degree of industry diversification under more severe government expropriation.

It is noteworthy that the relationship-specific rights to do business are likely to enable private entrepreneurs to expand the size of their existing business lines instead of diversification into new ones. Nevertheless, the following considerations suggest that industrial 
diversification within a region may well be a more viable strategy. (1) The market size of the region is relatively small. To reach the optimal scale of production, firms may need to supply their products to other regions to expand their existing business line (i.e., geographical diversification). ${ }^{21}$ (2) Given that the rights to do business are typically region-specific, however, setting up businesses in other regions will incur new one-time setup costs and ongoing levies imposed by other regional governments. Moreover, the existence of local protectionism deters interregional trade (Bai, Du, Tao, and Tong, 2004), putting further constraints on the viability of expanding the existing business lines across regions. (3) Regardless of whether the rights to do business are specific to a region or an industry, the fast-changing economic landscape dictates the rapid shift in the pattern of comparative profitability of different industries or business lines. Private entrepreneurs may well ride on their relationship-specific capital to enter the newly emerging profitable industries or businesses. (4) The government-administered projects are typically generated by the changing and varied demands in socioeconomic development, for which the expansion of existing business lines can hardly accommodate.

Two recently exposed high-profile cases in China might vividly illustrate the Chinesestyle diversification of private entrepreneurs. The first case is about how Mr. Xu Ming, a business tycoon, rose and fell with Mr. Bo Xilai, once one of the most powerful bureaucrats in China. ${ }^{22}$

When Mr. Bo became the mayor of Dalian, a major port city in northeastern China, in 1993, Mr. Xu had just founded a small business exporting shrimp and doing landfill work. Through the help of a Taiwanese-American businessman, Mr. Xu got to know Mr. Bo and his wife, Ms. Gu Kailai. At the time, to showcase his talent and administrative achievements, Mr. Bo launched a campaign to build the city into a shipping, fashion and information-technology hub and an international garden city with massive infrastructure developments. Mr. Xu, along with several other entrepreneurs, made financial contributions to Mr. Bo's ambitious plan to promote the city's image. As a reward for his support for Mr. Bo's campaign, the Dalian Shide, the company controlled by Mr. Xu, won landfill contracts for more than 30 large government construction projects. In order to beautify the buildings in the city, Mr. Bo was interested in introducing PVC products. Mr. Xu decided to take substantial business risks to start the manufacturing of PVC products. In 1995, Dalian Shide and a German company established a joint venture to make PVC door and window frames. Mr. Bo was pleased and ordered that many buildings in Dalian install PVC windows and doors with government subsidy provided to hasten installation.

\footnotetext{
${ }^{21}$ China's private enterprises could export their products to international markets so as to achieve the optimal scale of production. However, in 2000 (the year when the Survey was conducted), which was prior to China's entry to the World Trade Organization, those private enterprises had to export through state-owned trading companies, as a result of which their share in China's export was rather low.

${ }^{22}$ This case is based on "A Tycoon Rises and Falls With a Chinese Leader" (The Wall Street Journal, June 22, 2012) and other related news reports.
} 
The joint venture benefited tremendously from this government initiative. In addition, to help Mr. Bo realize his political ambitions, Mr. Xu purchased a landmark balloon for Dalian, which satisfied Mr. Bo and Ms. Gu's wish to promote the image of the city. Mr. $\mathrm{Xu}$ also acquired and further invested in Dalian's soccer team, the best one in China at that time, which Mr. Bo took an interest as a way to enhance the city's profile.

In maintaining close relations with Mr. Bo and his family, Mr. Xu also provided numerous personal favors and gifts. For example, Mr. Xu accompanied and financed Ms. $\mathrm{Gu}$ and her son in their trips to Britain for school hunting and covered her son's tuition. Mr. Xu bought a luxurious villa in Cannes, France for Mr. Bo's family.

Over the eight years (1993-2001) when Mr. Bo was the leader of Dalian, Mr. Xu made considerable investments into maintaining his relationships with Mr. Bo and his family, and reaped huge benefits from his relationship-specific rights to do business. His company grew into a major national conglomerate whose business covered plastics, finance and property, largely thanks to local government policies and government contracts linked to Mr. Bo's ambitious campaign.

Mr. Xu's relationship-specific rights to do business was also extended across regions and industries over time. In 2004, Mr. Bo moved to Beijing to serve as China's commerce minister in charge of issuing import and export licenses. Mr. Xu's Dalian Shide became one of a handful private companies that were granted licenses to import crude and refined oil. In 2007, Mr. Bo became the Party chief of Chongqing. By 2009, Dalian Shide executives set up a property development company in Chongqing to ride on the property market boom.

The second case is concerned with Ms. Ding Shumiao, a businesswoman from Shanxi province, and Mr. Liu Zhijun, the disgraced former railway minister. ${ }^{23}$ In the late 1990s, Ms. Ding got acquainted with Mr. Liu when he was the vice railway minister and won his trust. It is alleged that Mr. Liu regarded Ms. Ding as trustworthy and took a long-term strategy, i.e., he helped Ms. Ding establish and expand her business but did not ask for favors immediately and regularly. Only when he direly needed financial assistance did Mr. Liu ask Ms. Ding to help. To cultivate Ms. Ding as an entrepreneur, Mr. Liu himself and through his associates helped Ms. Ding acquire railway freight quota, with which Ms. Ding gained tremendous wealth from conducting coal transportation by herself and reselling quota to others. It is reported that Ms. Ding gained a profit of 440 million yuan from using or reselling railway freight quota in coal transportation in the period 2004-10 only.

In 2003, Mr. Liu became the railway minister. He started to launch his ambitious campaign for leap-frog development in railway construction and train speedup. He first carried out the campaign to raise the speed of trains, and then started up the massive

\footnotetext{
${ }^{23}$ This case is written on the basis of "Ding Shumiao, tycoon linked to ex-rail chief, stands trial" (South China Morning Post, September 25, 2013) and other related news reports.
} 
investment and construction scheme of the high-speed railway lines. In view of the new business opportunities arising from these campaigns, Ms. Ding founded Beijing Boyou Investment Company. It formed a joint venture with an Italian company to produce railway equipment first. With the expansion of Mr. Liu's high-speed railway project, Ms. Ding's company quickly expanded to the production of high-speed railway equipment and railway construction. Later, her company even entered business areas of advertisement and media, movies and TV plays, hotel, etc. Mr. Liu helped Ms. Ding and her families or associates win railway construction projects and gain profits of nearly 400 million yuan. In addition, Mr. Liu helped Ms. Ding to serve as middleman to win bids for highspeed railway projects for various enterprises, from which Ms. Ding obtained tremendous amounts of middleman commission fees (240 million yuan).

Ms. Ding returned the favor by providing financial assistance to Mr. Liu when he badly needed it. Ms. Ding spent 5 million yuan to help Mr. Liu lobby Party chieftains for the position of a provincial Party chief, which is generally considered as a stepping stone for even higher positions in the Party and the government. When one of Mr. Liu's subordinates was charged with corruption, Ms. Ding spent 44 million yuan in attempt to reduce his penalty in order to prevent him from revealing Mr. Liu's misdeeds. It is also alleged that Ms. Ding introduced quite a few actresses in her movie business to be Mr. Liu's mistresses.

These two cases show clearly that the Chinese-style diversification is often driven by the relationship-specific rights to do business. Firm diversification often relies on the business opportunities over which the bureaucrat has control. Hence, in the period when the bureaucrat remains in one region or one industry, the rights to do business are also region-specific or industry-specific. When the bureaucrat moves from one region or one industry to another, the region-specificity or industry-specificity also changes accordingly. Moreover, the industries that private entrepreneurs expand into are often the ones related to the bureaucrat's development plan and/or what the administrative power of the bureaucrat covers. Interestingly, the Chinese-style diversification is expected to generate considerable rents for entrepreneurs, which in turn enable entrepreneurs to pay for the maintenance of the relationship-specific rights to do business.

The Chinese-style diversification has important social welfare implications. Firstly, as mentioned above, given that the rights of doing business is often location specific, expanding an existing line of business geographically may not be a viable strategy even for the most efficient and most qualified private entrepreneurs. This is because they would have to face the one-time setup costs and ongoing levies of other regional governments if they were to expand the existing line of business geographically. This deters private firms from achieving economy of scale, and thus leads to efficiency losses. Secondly, the fact that firm diversification is typically driven by relationship-specific rights to do business means the firms obtaining licenses and entering some industries are often not 
the most efficient and most qualified producers, which will undermine product quality, retard productivity growth and harm economic efficiency improvement. Thirdly, the firms obtaining government contracts are in many cases serving as middlemen and outsourcing the projects to other producers. On the one hand, this will squeeze the profits of actual producers to create rents for the middlemen, which may prompt actual producers to lower product quality in order to win normal profits. On the other hand, to accommodate middleman commission, the government projects might offer a price much higher than the market price, which will lead to misuse of public funds. ${ }^{24}$

\section{Conclusion}

Diversified firms have been found to be very popular in many emerging economies. This is in contrast to the practices in developed economies, and it is also against the research findings using data of publicly listed firms that diversification has a negative impact on firm performance. While it has been argued that diversified firms may thrive in situations of poor economic institutions, much research is needed to substantiate this argument.

In this paper, we fill the gap by empirically investigating the impacts of government expropriation on firm diversification. Using a survey data set of private enterprises in China, we find that government expropriation has a positive impact on firm diversification. In order to conclude that our finding is not biased due to omitted variables and reverse causality, we conduct an instrumental variable estimation using three alternative instruments and a series of robustness checks. To understand how in China government expropriation leads to diversification of private enterprises, we also present two case studies to highlight the extra costs that China's private entrepreneurs need to bear for doing businesses. Our discussion demonstrates that the Chinese-style firm diversification is closely associated with China's state capitalism. Treated discriminatively as adopted kids, private entrepreneurs make efforts to win trust from bureaucrats and gain relationship-specific rights to do business, and then leverage their privileges into new business lines often following government bureaucrats' new development initiatives and signature projects.

Our study highlights the fundamental importance of economic institutions, particularly, property rights protection (i.e., the institutions constraining government expropriation of private properties), for corporate decisions. It also sheds light on the institutional foundations for the divergent patterns of firm diversification between emerging economies and developed economies. We show that firm diversification in China often involves overdiversification induced by government discrimination and expropriation under China's state capitalism model. Once the institutional environment for China's private sector

\footnotetext{
${ }^{24}$ For example, there are reports that the procurement costs of chairs in high-speed trains are much higher than the market price (see, e.g., Wang, Yu, and Wang, 2013).
} 
improves, we expect private enterprises to exhibit less industrial diversification, more geographical diversification, and be more efficient and competitive, and ultimately account for a greater share in China's overall economy. 


\section{References}

[1] Acemoglu, Daron, Simon Johnson, and Todd Mitton (2009) "Determinants of Vertical Integration: Financial Development and Contracting Costs", Journal of Finance 63, 1251-1290.

[2] Acemoglu, Daron, Simon Johnson, and James A. Robinson (2001) "The Colonial Origins of Comparative Development: An Empirical Investigation", American Economic Review 91, 1369-1401.

[3] Acemoglu, Daron, Simon Johnson, and James A. Robinson (2002) "Reversal of Fortune: Geography and Institutions in the Making of the Modern World Income Distribution", Quarterly Journal of Economics 117, 1231-1294.

[4] Angrist, Joshua and Jörn-Steffen Pischke (2009) Mostly Harmless Econometrics, Princeton University Press.

[5] Asian Development Bank (2003) "The Development of Private Enterprises in the People's Republic of China", Asian Development Bank Publication, March.

[6] Bai, Chong-En, Yingjuan Du, Zhigang Tao, and Sarah Y. Tong (2004) "Local protectionism and regional specialization: evidence from China's industries", Journal of International Economics 63, 397-417.

[7] Bai, Chong-En, Jiangyong Lu, and Zhigang Tao (2006) "Property Rights Protection and Access to Bank Loans", Economics of Transition 14, 611-628.

[8] Blasi, Joseph, Maya Kroumova, and Douglas Kruse (1997) Kremlin Capitalism: Privatizing the Russian Economy, ILR Press: An Imprint of Cornell University Press, Ithaca and London.

[9] Brandt, Loren and Hongbin Li (2003) "Bank Discrimination in Transition Economies: Ideology, Information, or Incentives?", Journal of Comparative Economics 31, 387-413.

[10] Cai, Hongbin, Hanming Fang, and Lixin Colin Xu (2011) "Eat, Drink, Firms and Government: An Investigation of Corruption from Entertainment and Travel Costs of Chinese Firms", Journal of Law and Economics 54, 55-78.

[11] Camp, Roderic A. (1989) Entrepreneurs and Politics in Twentieth-Century Mexico, New York: Oxford University Press.

[12] Che, Jiahua and Yingyi Qian (1998) "Insecure Property Rights And Government Ownership Of Firms", Quarterly Journal of Economics 113, 467-496. 
[13] Clarke, Donald C. (1996) "Power and Politics in the Chinese Court System: The Enforcement of Civil Judgment", Columbia Journal of Asian Law 10, 1-92,

[14] Cull, Robert, and Lixin Colin Xu (2005) "Institutions, Ownership, and Finance: the Determinant of Profit Reinvestment among Chinese Firms", Journal of Financial Economics 77, 117-146.

[15] Du, Julan, Yi Lu, and Zhigang Tao (2008) "Economic Institutions and FDI Location Choice: Evidence from US Manufacturing Firms in China", Journal of Comparative Economics 36, 412-429.

[16] Du, Julan, Yi Lu, and Zhigang Tao (2012) "Contracting Institutions and Vertical Integration: Evidence from China's Manufacturing Firms", Journal of Comparative Economics 40, 89-107.

[17] Fan, Joseph P.H., Jun Huang, Randall Morck, and Bernard Y. Yeung (2008) "Institutional Determinants of Vertical Integration: Evidence from China", working paper.

[18] Ghemawat, Pankaj and Tarun Khanna (1998) "The Nature of Diversified Business Group: A Research Design and Two Case Studies", Journal of Industrial Economics $46,35-61$.

[19] Jin, Hehui and Yingyi Qian (1998) "Public Ownership of Firms: Evidence from Rural China", Quarterly Journal of Economics 113, 773-808.

[20] Johnson, Simon, Daniel Kaufmann, and Pablo Zoido-Lobaton (1998) "Regulatory Discretion and the Unofficial Economy", American Economic Review 88, 387-392.

[21] Johnson, Simon, John McMillan, and Christopher Woodruff (2002) "Property Rights and Finance", American Economic Review, 22, 1335-1356.

[22] Keister, Lisa A. (2000) Chinese Business Groups: The Structure and Impact of Interfirm Relations During Economic Development, Oxford University Press.

[23] Khanna, Tarun and Krishna Palepu (1996) "Corporate Scope and Institutional Context: An Empirical Analysis of Diversified Indian Business Groups", Harvard Business School Working Paper \#96-051.

[24] Khanna, Tarun and Krishna Palepu (1997) "Why Focused Strategies may be Wrong for Emerging Markets", Harvard Business Review 75, 41-51.

[25] Khanna, Tarun and Krishna Palepu (2000a) "Is Group Affiliation Profitable in Emerging Markets? An Analysis of Diversified Indian Business Groups", Journal of Finance 55, 867-891. 
[26] Khanna, Tarun and Krishna Palepu (2000b) "The Future of Business Groups in Emerging Markets: Long-run Evidence from Chile", Academy of Management Journal 43, 268-85.

[27] Khanna, Tarun and Yishay Yafeh (2005) "Business Groups and Risk Sharing Around the World", Journal of Business 78, 301-340.

[28] Khanna, Tarun and Yishay Yafeh (2007) "Business Groups in Emerging Markets: Paragons or Parasites?", Journal of Economic Literature 45, 331-372.

[29] Li, Hongbin (2003) "Government's Budget Constraint, Competition and Privatization", Journal of Comparative Economics 31, 380-398.

[30] Li, Hongbin, Linsheng Meng, and Junsen Zhang (2006) "Why Do Entrepreneurs Enter Politics? Evidence from China", Economic Inquiry 44, 559-578.

[31] Li, Hongbin and Scott Rozelle (2004). "Insider Privatization with a Tail: The Screening Contract and Performance of Privatized Firms in Rural China", Journal of Development Economics 75, 1-26.

[32] Lu, Yi, Ivan P.L. Png, and Zhigang Tao (2013) "Do Institutions not Matter in China? Evidence from Manufacturing Enterprises", Journal of Comparative Economics 41, 74-90.

[33] Martin, John D. and Akin Sayrak (2003) "Corporate Diversification and Shareholder Value: A Survey of Recent Literature", Journal of Corporate Finance 9, 37-57.

[34] McMillan, John and Christopher Woodruff (1999) "Interfirm Relationships And Informal Credit In Vietnam", Quarterly Journal of Economics 114, 1285-1320.

[35] North, Douglass C. (1991) "Institutions", Journal of Economic Perspectives 5, 97112.

[36] Silverman, Brian S. (1999) "Technological Resources and the Direction of Corporate Diversification: Toward an Integration of the Resource-Based View and Transaction Cost Economics", Management Science 45, 1109-1124.

[37] Staiger, Douglas and James Stock (1997) "Instrumental Variables Regression with Weak Instruments", Econometrica 65, 557-586.

[38] Wang, Xiaobin, Ning Yu, and Cheng Wang (2013) Way is Formless, Guangzhou, China: Nanfang Daily Press.

[39] World Bank (2008) Doing Business in China 2008, Beijing, China: Social Science Academic Press. 
[40] Wooldridge, Jeffrey M. (2003) "Cluster-Sample Methods in Applied Econometrics", American Economic Review 93, 133-138.

[41] Wooldridge, Jeffrey M. (2006) "Cluster Sample Methods in Applied Econometrics: An Extended Analysis", working paper.

[42] Wu, Wenbo (2003) "The Origin of Private Property Rights in China: A Game Between Central and Local Governments", working paper.

[43] Zhang, Xiaobo (2006) "Asymmetric Property Rights in China's Economic Growth", working paper, International Food Policy Research Institute. 
Table 1: Summary Statistics

\begin{tabular}{|c|c|c|c|c|c|}
\hline Variable & Obs & Mean & $\begin{array}{l}\text { Std. } \\
\text { Dev. }\end{array}$ & Min & Max \\
\hline Diversification & 2798 & 0.334 & 0.472 & 0.000 & 1.000 \\
\hline Number of Industries & 2798 & 0.447 & 0.733 & 0.000 & 3.000 \\
\hline Government Expropriation & 2033 & 0.000 & 1.296 & -1.509 & 2.608 \\
\hline \multicolumn{6}{|c|}{$\begin{array}{l}\text { Entrepreneurial Characteristics } \\
\text { Human Capital }\end{array}$} \\
\hline Education & 2793 & 12.601 & 2.854 & 0.000 & 19.000 \\
\hline Age & 2777 & 43.429 & 8.347 & 22.000 & 75.000 \\
\hline Managerial Experience & 2795 & 4.279 & 7.272 & 0.000 & 61.000 \\
\hline SOE Cadre & 2798 & 0.364 & 0.481 & 0.000 & 1.000 \\
\hline \multicolumn{6}{|l|}{ Political Capital } \\
\hline CPC Membership & 2798 & 0.158 & 0.365 & 0.000 & 1.000 \\
\hline CPPCC Membership & 2798 & 0.407 & 0.491 & 0.000 & 1.000 \\
\hline Government Cadre & 2798 & 0.075 & 0.264 & 0.000 & 1.000 \\
\hline Social Capital & & & & & \\
\hline Donation & 2590 & 0.929 & 0.258 & 0.000 & 1.000 \\
\hline Social Status & 2728 & 6.672 & 1.958 & 1.000 & 10.000 \\
\hline \multicolumn{6}{|l|}{ Firm Characteristics } \\
\hline Firm Age & 2535 & 1.652 & 0.714 & 0.000 & 3.045 \\
\hline Firm Size & 2653 & 4.073 & 1.344 & 0.000 & 9.903 \\
\hline Contracting Institutions & 2793 & 0.398 & 0.490 & 0.000 & 1.000 \\
\hline Financing Institution & 2792 & 0.602 & 0.490 & 0.000 & 1.000 \\
\hline Taxation Policy & 2792 & 0.532 & 0.499 & 0.000 & 1.000 \\
\hline Equal Treatment & 2792 & 0.392 & 0.488 & 0.000 & 1.000 \\
\hline
\end{tabular}


Table 2, Comparison of Diversified Firms Group and Focused Firms Group

\begin{tabular}{|c|c|c|c|c|c|c|}
\hline & $\begin{array}{c}1 \\
\text { Diversification=0 } \\
\text { Mean }\end{array}$ & $\begin{array}{c}2 \\
\text { Diversification=1 } \\
\text { Mean }\end{array}$ & $\begin{array}{c}3 \\
\text { t-statistic } \\
\text { Mean (1)-Mean (2) }\end{array}$ & $\begin{array}{c}4 \\
\text { Diversification=0 } \\
\text { Median }\end{array}$ & $\begin{array}{c}5 \\
\text { Diversification=1 } \\
\text { Median }\end{array}$ & $\begin{array}{c}6 \\
\text { Wilcoxon } \\
\text { z-statistic }^{-} \\
\text {Median (4) -Median (5) }\end{array}$ \\
\hline $\begin{array}{l}\text { Government Expropriation } \\
\text { Entrepreneurial Characteristics } \\
\text { Human Capital }\end{array}$ & -0.090 & 0.173 & $-4.35 * * *$ & -0.457 & 0.550 & $-4.72 * * *$ \\
\hline Education & 12.265 & 13. 271 & $-8.91 * * *$ & 12 & 12 & $-9.08 * * *$ \\
\hline Age & 43.836 & 42.617 & 3. $64 * * *$ & 44 & 42 & 3. $66 * * *$ \\
\hline Managerial Experience & 4. 053 & 4. 730 & $-2.32 * *$ & 0 & 0 & $-3.81 * * *$ \\
\hline $\begin{array}{l}\text { SOE Cadre } \\
\text { Political Capital }\end{array}$ & 0.337 & 0.419 & $-4.25 * * *$ & 0 & 0 & $-4.24 * * *$ \\
\hline Government Cadre & 0.060 & 0.105 & $-4.26 * * *$ & 0 & 0 & $-4.24 * * *$ \\
\hline CPC Membership & 0.149 & 0.177 & $-1.88 *$ & 0 & 0 & $-1.88 *$ \\
\hline $\begin{array}{l}\text { CPPCC Membership } \\
\text { Social Capital }\end{array}$ & 0.369 & 0.484 & $-5.86 * * *$ & 0 & 0 & $-5.83 * * *$ \\
\hline Donation & 0.912 & 0.962 & $-4.70 * * *$ & 1 & 1 & $-4.68 * * *$ \\
\hline Social Status & 6.516 & 6.986 & $-5.94 * * *$ & 6 & 7 & $-6.38 * * *$ \\
\hline Firm Characteristics & & & & & & \\
\hline Firm Age & 2.201 & 2.288 & $-3.21 * * *$ & 2.398 & 2.398 & $-2.62 * * *$ \\
\hline Firm Size & 3.869 & 4. 478 & $-11.27 * * *$ & 3.829 & 4. 407 & $-10.38 * * *$ \\
\hline Contracting Institutions & 0.388 & 0.419 & -1.57 & 0 & 0 & -1.57 \\
\hline Financing Institution & 0.560 & 0.685 & $-6.44 * * *$ & 1 & 1 & $-6.39 * * *$ \\
\hline Taxation Policy & 0.520 & 0.556 & $-1.80 *$ & 1 & 1 & $-1.80 *$ \\
\hline Equal Treatment & 0.349 & 0.476 & $-6.54 * * *$ & 0 & 0 & $-6.49 * * *$ \\
\hline
\end{tabular}

Note: $*, * *$ and $* * *$ represent statistical significance at the $10 \%, 5 \%$ and $1 \%$ level, respectively. 
Table 3: Benchmark Regression Results

\begin{tabular}{|c|c|c|c|c|c|c|c|}
\hline & 1 & 2 & 3 & 4 & 5 & 6 & 7 \\
\hline Pane1 A: OLS Estimation & \multicolumn{7}{|c|}{ Dependent Variable is Diversification } \\
\hline Government Expropriation & $\begin{array}{l}0.035 * * * \\
(0.008)\end{array}$ & $\begin{array}{l}0.031 * * * \\
(0.008)\end{array}$ & $\begin{array}{c}0.029 * * * \\
(0.008)\end{array}$ & $\begin{array}{c}0.025 * * * \\
(0.008)\end{array}$ & $\begin{array}{l}0.020 * * \\
(0.008)\end{array}$ & $\begin{array}{c}0.018 * * \\
(0.008)\end{array}$ & $\begin{array}{l}0.014 * \\
(0.008)\end{array}$ \\
\hline $\begin{array}{l}\text { Entrepreneurial Characteristics } \\
\text { Human Capital }\end{array}$ & & & & & & & \\
\hline Education & & $\begin{array}{l}0.024 * * * \\
(0.004)\end{array}$ & $\begin{array}{l}0.024 * * * \\
(0.004)\end{array}$ & $\begin{array}{l}0.022 * * * \\
(0.004)\end{array}$ & $\begin{array}{l}0.019 * * * \\
(0.004)\end{array}$ & $\begin{array}{l}0.014 * * * \\
(0.004)\end{array}$ & $\begin{array}{l}0.014 * * * \\
(0.004)\end{array}$ \\
\hline Managerial Experience & & $\begin{array}{c}0.002 \\
(0.001)\end{array}$ & $\begin{array}{l}0.001 \\
(0.001)\end{array}$ & $\begin{array}{c}0.001 \\
(0.001)\end{array}$ & $\begin{array}{c}0.001 \\
(0.002)\end{array}$ & $\begin{array}{c}0.002 \\
(0.001)\end{array}$ & $\begin{array}{c}0.002 \\
(0.001)\end{array}$ \\
\hline SOE Cadre & & $\begin{array}{l}0.072 * * * \\
(0.023)\end{array}$ & $\begin{array}{l}0.077 * * * \\
(0.023)\end{array}$ & $\begin{array}{l}0.082 * * * \\
(0.024)\end{array}$ & $\begin{array}{c}0.091 * * * \\
(0.024)\end{array}$ & $\begin{array}{l}0.071 * * * \\
(0.024)\end{array}$ & $\begin{array}{c}0.037 \\
(0.024)\end{array}$ \\
\hline CPC Membership & & & $\begin{array}{l}0.037 \\
(0.028)\end{array}$ & $\begin{array}{c}0.020 \\
(0.029)\end{array}$ & $\begin{array}{l}-0.015 \\
(0.031)\end{array}$ & $\begin{array}{l}-0.021 \\
(0.030)\end{array}$ & $\begin{array}{l}-0.021 \\
(0.030)\end{array}$ \\
\hline СРPCC Membership & & & $\begin{array}{c}0.089 * * * \\
(0.021)\end{array}$ & $\begin{array}{l}0.061 * * * \\
(0.023)\end{array}$ & $\begin{array}{c}0.017 \\
(0.024)\end{array}$ & $\begin{array}{c}0.002 \\
(0.023)\end{array}$ & $\begin{array}{l}-0.010 \\
(0.023)\end{array}$ \\
\hline Social Capital & & & & & & & \\
\hline Donation & & & & $\begin{array}{l}0.136 * * * \\
(0.035)\end{array}$ & $\begin{array}{c}0.091 * * * \\
(0.037)\end{array}$ & $\begin{array}{c}0.077 * * \\
(0.037)\end{array}$ & $\begin{array}{c}0.057 \\
(0.035)\end{array}$ \\
\hline Social Status & & & & $\begin{array}{l}0.029 * * * \\
(0.006)\end{array}$ & $\begin{array}{l}0.026 * * * \\
(0.006)\end{array}$ & $\begin{array}{c}0.024 * * * \\
(0.006)\end{array}$ & $\begin{array}{l}0.021 * * * \\
(0.006)\end{array}$ \\
\hline $\begin{array}{l}\text { Firm Characteristics } \\
\text { Firm Age }\end{array}$ & & & & & $0.045 * * *$ & $0.041 * *$ & $0.031 *$ \\
\hline
\end{tabular}




\begin{tabular}{|c|c|c|c|c|c|c|c|}
\hline \multirow{2}{*}{ Firm Size } & & & & & $(0.017)$ & $(0.016)$ & $(0.016)$ \\
\hline & & & & & $\begin{array}{c}0.041 * * * \\
(0.009)\end{array}$ & $\begin{array}{c}0.054 * * * \\
(0.009)\end{array}$ & $\begin{array}{c}0.042 * * * * \\
(0.010)\end{array}$ \\
\hline Contracting Institutions & & & & & $\begin{array}{l}-0.028 \\
(0.022)\end{array}$ & $\begin{array}{l}-0.027 \\
(0.021)\end{array}$ & $\begin{array}{l}-0.018 \\
(0.021)\end{array}$ \\
\hline Financing Institution & & & & & $\begin{array}{c}0.083 * * * \\
(0.022)\end{array}$ & $\begin{array}{c}0.086 * * * \\
(0.022)\end{array}$ & $\begin{array}{c}0.079 * * * \\
(0.022)\end{array}$ \\
\hline Taxation Policy & & & & & $\begin{array}{l}-0.017 \\
(0.022)\end{array}$ & $\begin{array}{l}-0.005 \\
(0.022)\end{array}$ & $\begin{array}{l}-0.005 \\
(0.022)\end{array}$ \\
\hline Equal Treatment & & & & & $\begin{array}{c}0.060 * * * \\
(0.022)\end{array}$ & $\begin{array}{c}0.056 * * * \\
(0.022)\end{array}$ & $\begin{array}{c}0.033 \\
(0.022)\end{array}$ \\
\hline $\begin{array}{l}\text { Industrial Characteristics } \\
\text { Industry Dummies } \\
\text { Regional Characteristics }\end{array}$ & & & & & & Yes & Yes \\
\hline Region Dummies & & & & & & No & Yes \\
\hline Number of Observations & 2,033 & 2,018 & 2,018 & 1,887 & 1,822 & 1,822 & 1,822 \\
\hline $\mathrm{R}-$ squared & 0.0092 & 0.0498 & 0.0624 & 0.0819 & 0.1119 & 0.1572 & 0.2088 \\
\hline F-test & 19. 15 & 20.63 & 16.96 & 18.61 & 18.05 & 16.41 & - \\
\hline$p$-value for $\mathrm{F}$-test & 0.0000 & 0.0000 & 0.0000 & 0.0000 & 0.0000 & 0.0000 & - \\
\hline \multirow{2}{*}{$\begin{array}{l}\text { Panel B: Probit Estimation } \\
\text { Government Expropriation }\end{array}$} & \multicolumn{7}{|c|}{ Dependent Variable is Diversification } \\
\hline & $\begin{array}{c}0.035 * * * \\
(0.008)\end{array}$ & $\begin{array}{c}0.032 * * * \\
(0.008)\end{array}$ & $\begin{array}{c}0.030 * * * \\
(0.008)\end{array}$ & $\begin{array}{c}0.025 * * * \\
(0.008)\end{array}$ & $\begin{array}{c}0.022 * * \\
(0.009)\end{array}$ & $\begin{array}{c}0.021 * * \\
(0.009)\end{array}$ & $\begin{array}{l}0.017 * \\
(0.010)\end{array}$ \\
\hline
\end{tabular}

Note: White-robust standard errors are reported in the parenthesis. $* *$ and $* * *$ represent statistical significance at the $5 \%$ and $1 \%$ level, respectively. Constant term is included in all regression but results are not reported to save space. Panel B reports the marginal effect of Probit estimation. 
Table 4: Instrumental Variable Regression Results

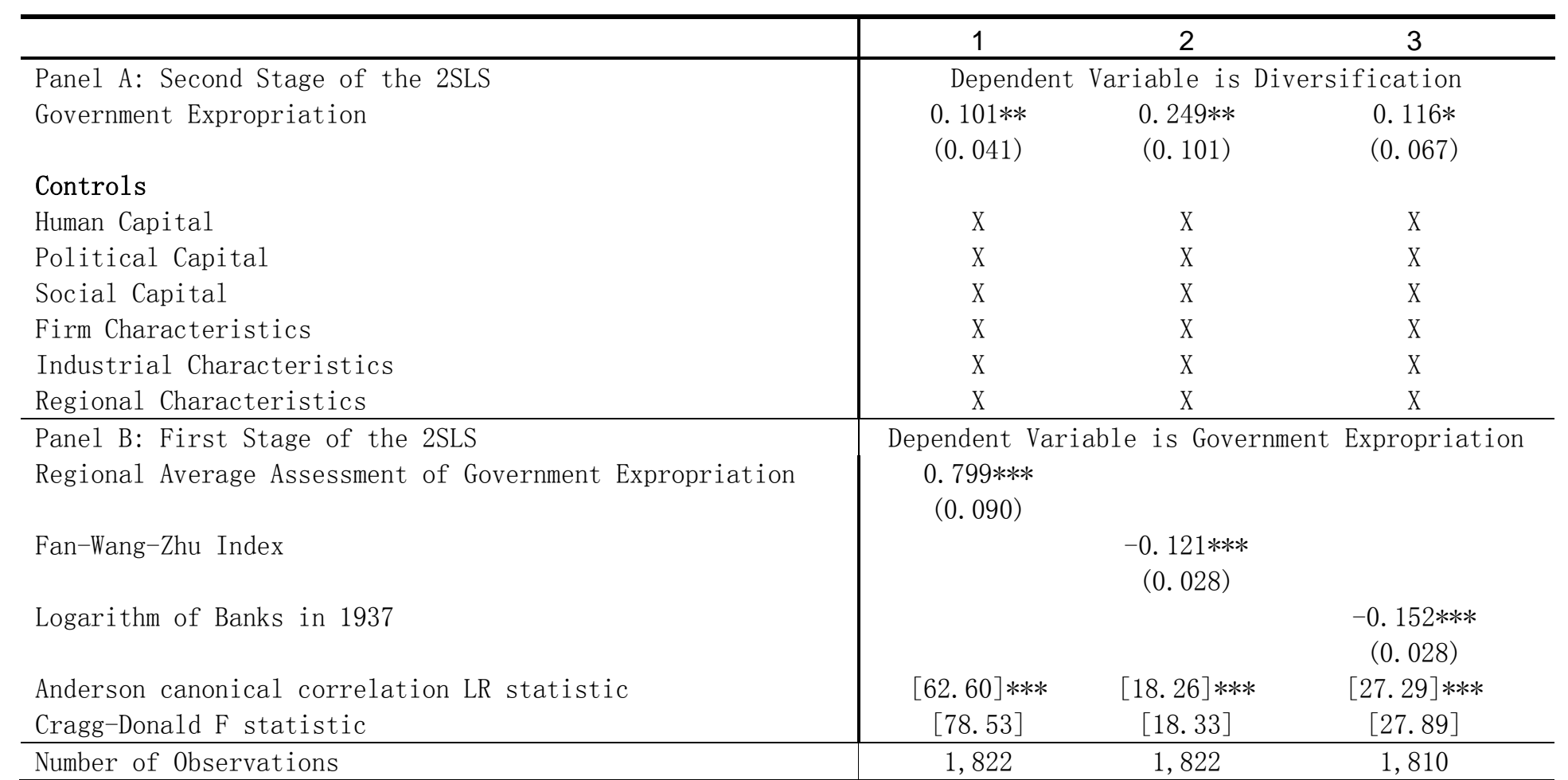

Note: White-robust standard errors are reported in the parenthesis. ${ }^{*}, * *$ and $* * *$ represent statistical significance at the $10 \%, 5 \%$ and $1 \%$ level, respectively. Constant term is included in all regression but the estimated coefficients are not reported to save space. In all regressions, the first stage of 2SLS includes the same control variables as those in the second stage but the estimated coefficients are not reported to save space. 
Table 5: Robustness Checks

\begin{tabular}{|c|c|c|c|c|}
\hline Sample & $\begin{array}{c}1 \\
\text { Whole Sample }\end{array}$ & Whole Sample & $\begin{array}{c}3 \\
\text { Subsample } 1\end{array}$ & $\begin{array}{c}4 \\
\text { Subsample } 2\end{array}$ \\
\hline $\begin{array}{l}\text { Panel A: Second Stage of 2SLS } \\
\text { Government Expropriation }\end{array}$ & $\begin{array}{c}\text { Dependent Variable is Number of } \\
\text { Industries } \\
0.570 * * * \\
(0.104)\end{array}$ & $\begin{array}{l}\text { Dependent } \\
0.288 * * * \\
(0.123)\end{array}$ & $\begin{array}{c}0.248 * * \\
(0.121)\end{array}$ & $\begin{array}{l}\text { sification } \\
\begin{array}{l}0.308 * * \\
(0.147)\end{array}\end{array}$ \\
\hline $\begin{array}{l}\text { Controls } \\
\text { Human Capital } \\
\text { Political Capital } \\
\text { Social Capital } \\
\text { Firm Characteristics } \\
\text { Industrial Characteristics } \\
\text { Regional Characteristics }\end{array}$ & $\begin{array}{l}X \\
X \\
X \\
X \\
X \\
X\end{array}$ & $\begin{array}{l}X \\
X \\
X \\
X \\
X \\
X\end{array}$ & $\begin{array}{l}X \\
X \\
X \\
X \\
X \\
X\end{array}$ & $\begin{array}{l}X \\
X \\
X \\
X \\
X \\
X\end{array}$ \\
\hline $\begin{array}{l}\text { Panel B: First Stage of 2SLS } \\
\text { Fan-Wang-Zhu Index } \\
\text { Anderson canonical correlation LR statistic } \\
\text { Cragg-Donald F statistic }\end{array}$ & $\begin{array}{l}-0.049 * * * \\
\quad(0.014) \\
{[11.97] * * *} \\
\quad[12.03]\end{array}$ & $\begin{array}{l}\text { Variable is } \\
-0.128 * * * \\
\quad(0.035) \\
{[13.66] * * *} \\
{[13.61]}\end{array}$ & $\begin{array}{l}\text { ernment Exprc } \\
-0.125 * * * \\
\quad(0.034) \\
{[13.82] * * *} \\
{[13.96]}\end{array}$ & $\begin{array}{l}\text { iation } \\
\text {-0. } 115 * * * \\
\quad(0.036) \\
{[10.15] * * *} \\
\quad[10.13]\end{array}$ \\
\hline $\begin{array}{l}\text { Panel C: OLS } \\
\text { Government Expropriation }\end{array}$ & $\begin{array}{l}0.549 * * * \\
(0.014)\end{array}$ & $\begin{array}{l}0.024 * * \\
(0.010)\end{array}$ & $\begin{array}{c}0.011 \\
(0.010)\end{array}$ & $\begin{array}{l}0.021 * * \\
(0.010)\end{array}$ \\
\hline Number of Observations & 2,395 & 1,208 & 1,252 & 1,207 \\
\hline
\end{tabular}

Note: White-robust standard errors are reported in the parenthesis. $*$, ** and $* * *$ represent statistical significance at the $10 \%, 5 \%$ and $1 \%$ level, respectively. Constant term is included in all regression but the estimated coefficients are not reported to save space. In all regressions, the first stage of 2SLS includes the same control variables as those in the second stage but the estimated coefficients are not reported to save space. 